\title{
Serum gamma-glutamyltransferase activity: Inhibitory study in patient of hepatitis
}

\author{
Namama S.Talabani \\ University of Sulaimania-Faculty of Science-Chemistry department
}

\begin{abstract}
Elevation of gamma-glutamyltransferase (GGT) activity has been implicated in many pathologies, and clinical inhibitors of GGT are under development for use in the treatment of liver, cancer, bone, and other diseases. In this study we try to find other new inhibitor of GGT, we used new polar amino acid (threonine) as inhibitor ,kinetic studies provide insight into the mechanism of inhibition. New uncompetitive inhibitors of physiological GGT reaction we found, development of new inhibitors is essential for exploiting GGT as a therapeutic target. L-threonine, in the presence study was detected as uncompetitive inhibitor, Km values were determined; we characterized the kinetic properties of GGT under a standard set of condition. Serum GGT was analyzed in healthy cases (normal 25:mean $\pm S D$ ) age $30 \pm 12$ years, $(16.71 \pm 0.87$ ), the mean values of GGT levels were statistically significantly higher in liver syndrome(70.79 \pm 1.24 ), and this values decreased in the presence of inhibitor to $(60.82 \pm 0.87)$.
\end{abstract}

Keyword : Gamma-glutamyltransferase, inhibitor,threonine, hepatitis

\section{Introduction:}

GGT (EC.2.3.2.2) is a cell surface enzyme that cleaves gamma-glutamyl bonds of extracellular subctances including glutathione (GSH),GSH s-conjugates and leukotriene C (Elce and Broxmeyer,1976; Curthoys and Hughey,1979; Wickham,West, et al,2011).

Elevation of serum $\mathrm{y}$-glutamyltransferase(GGT) activity is frequently interpreted as an index of hepatobiliary dysfunction and as a nonspecific marker of excessive alcohol use(J.B.Whitifield,2001).And elevation of GGT has been implicated in pulmonary disease,cardiovascular disease and cancer(Lowry,Allister et al ,2008;Lee,Evan et al,2007; Hanigan,Gallagher et al,1999)

GGT has been demonstrated in various human and animal organs,including kidneys,liver and spleen. It is also present in various body fluids,such as saliva,serum,bile and urine (Sener,1997;Nemesanzky and lott,1985). GGT is present in serum as part of several molecular complexes, with distinct physiochemical properties(Huseby,1982; Wenham,Horn et al,1984).

GGT measurement was introduced into clinical laboratories some 45 years ago, and over that times a large amount of information on factors influencing its activity in serum has accumulated. Theories have been put forward about its normal function within the body and its role in numerous pathological conditions.

Threonine is an is an $\alpha$-amino acid, this essential amino acid is classified as polar (Moss,1984), while the highest growth and specific growth and specific growth rate were showed in diet containing $1.7 \%$ threonine. Dietary threonine imbalance is known to reduce the growth of the small intestine,liver,and skeletal muscle in young animals, an excess or a deficiency of dietary threonine decreases protein synthesis in rapidly growing tissues(Xu,Shiyan et al,2007;Benakappa and Varghese,2013).

The present work, we have investigated the inhibitory effect of essential amino acid (L-threonine) on serum GGT activity in patient's with hepatitis, at the same time we study the effect of time on the activity, the results would help to select the new inhibitor which might useful for the treatment of some hepatitis.

\section{Collection of samples:}

\section{Materials and Methods:}

Blood analysis is usually done on venous of capillary blood. (45) samples of blood were throughout the investigation of GGT enzyme activity ( age 20-50 years), these samples were diagnosed by consultants and proved by liver function test. They are no accompanied disease. Healthy normal (25) were used as controls. The blood left at room temperature after clot formation the serum isolated by centrifugation . serum obtained was use on the same day of experiment.

\section{Chemicals:}

These were chosen for specific GGT activity determination and all other experiments related, they were of analytical grade, and highly purified, purchased from BDH and FLUKA. 


\section{Gamma-glutamyltransferase assay:}

The GGT activity was determined by the hydrolysis of g-glutamyl p-nitroanilide in the presence of the acceptor (Szasz,1969 ;1974). Standard assay included final reagent concentration 2mM of gamma-glutamyl pnitroanilide, $62 \mathrm{mM}$ of glycylglycine and $95 \mathrm{mM}$ of Tris- $\mathrm{HCl}, \mathrm{pH} 8.1$. The rate of p-nitroanilide formation was measured at $405 \mathrm{~nm}$ by using spectrophotometer. The results were expressed as $\mathrm{U} / \mathrm{L}$, one unit of enzyme represents the amount of enzyme that catalyzes the release of $1 \mathrm{mmol}$ of nitroaniline $/ \mathrm{min}$.

\section{Inhibition studies:}

The GGT inhibition with L-threonine was studied by using Tris- $\mathrm{HCl}$ buffer containing various concentration of gamma-glutamyl p-nitroanilide $(0.5,1,1.5,2,2.5,3 \mathrm{mmol} / \mathrm{L})$ and $62 \mathrm{mmol}$ of glycylglycine per liter. L-threonine $(2.5 \mathrm{mM})$ were added to the reaction mixture. The GGT activities were assayed after $1 \mathrm{~min}$ incubation with the inhibitors.

Apparent Km and apparent Vmax values were determined from Michaelies-Menten and Lineweaver Burk plots for gamma-glutamyl p-nitroanilide.

\section{Results:}

Investigating GGT activity data obtained shows an elevation of the activity in hepatitis (70.79 \pm 1.24 $\mathrm{U} / \mathrm{L})$ when compared with normal activity $(16.71 \pm 0.87 \mathrm{U} / \mathrm{L})$ (table 1$)$. In presence of L-threonine $(2.5 \mathrm{mM} / \mathrm{L})$ uncompetitively inhibited of the serum GGT activity at $2 \mathrm{mmol} / \mathrm{L}$ concentration of gamma-glutamyl pnitroanilide (fig 1).

\section{Determination of Vmax and Km values:-}

These values of Vmax and Km were achieved using Michaelis-Menten analysis fig(2)(table2), the data analysed were confirmed by plotting Lineweaver-burk plot fig(3).By these figures we can detect L-threonine as uncompetitive inhibitor.

Fig(1): effect of (2mM)of L-threonine on GGT activity in hepatitis sera

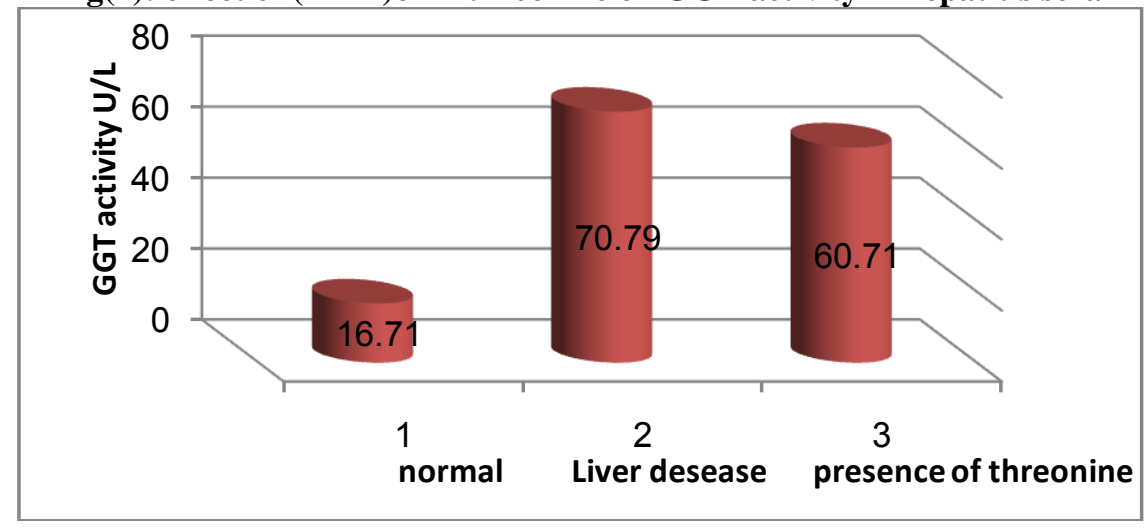

Table (I): GGT-enzyme activity inhibition using L-threonine $(2 \mathrm{mM})$ in normal and hepatitis sera

\begin{tabular}{|c|c|}
\hline Case & GGT activity $($ mean \pm SD) U/L \\
\hline Normal & $16.71 \pm 0.87$ \\
\hline Hepatitis sera & $70.79 \pm 1.24$ \\
\hline Presence of L-threonine $(2 \mathrm{mM})$ & $60.82 \pm 0.87$ \\
\hline
\end{tabular}

Table (II): Km and Vmax values for serum GGT in( hepatitis and presence of L-threonine $2 \mathrm{mM}$ )

\begin{tabular}{|c|c|c|}
\hline parameter & $\begin{array}{c}\text { GGT activity without L- } \\
\text { threonine }\end{array}$ & $\begin{array}{c}\text { GGT activity in presence of } \\
\text { L-threonine }\end{array}$ \\
\hline $\mathrm{Km}(\mathrm{mM})$ & 1.25 & 1 \\
\hline $\mathrm{Vmax}(\mathrm{U} / \mathrm{L})$ & 12.5 & 10 \\
\hline
\end{tabular}




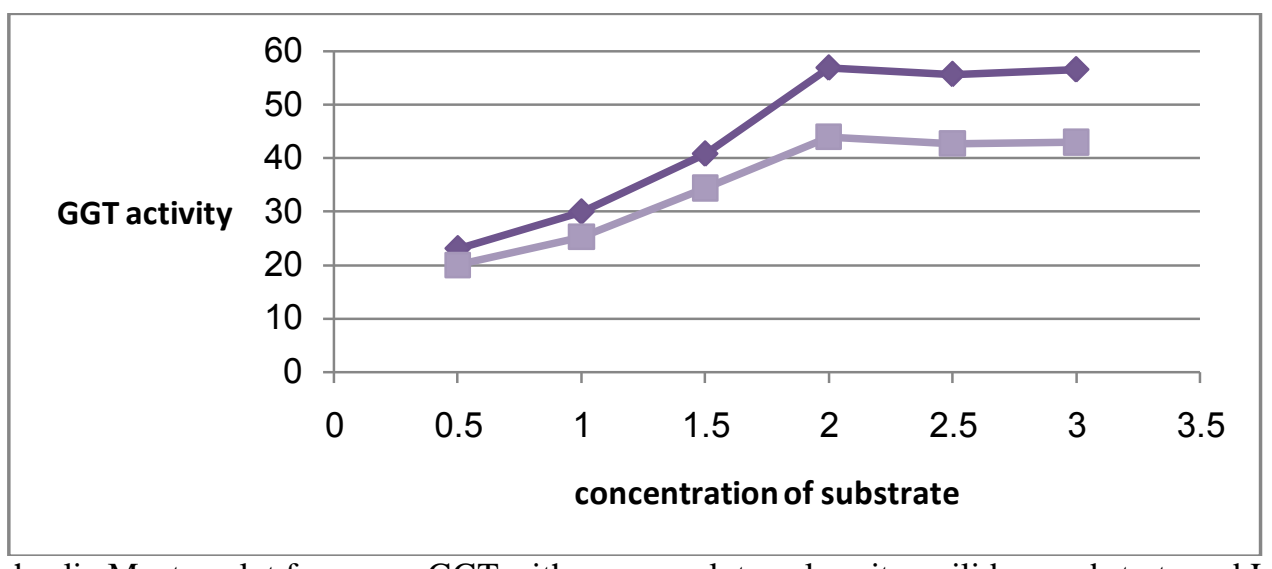

Fig(2): Michaelis-Menten plot for serum GGT with gamma-glutamyl p-nitroanilide as substrate and L-threonine as inhibitor

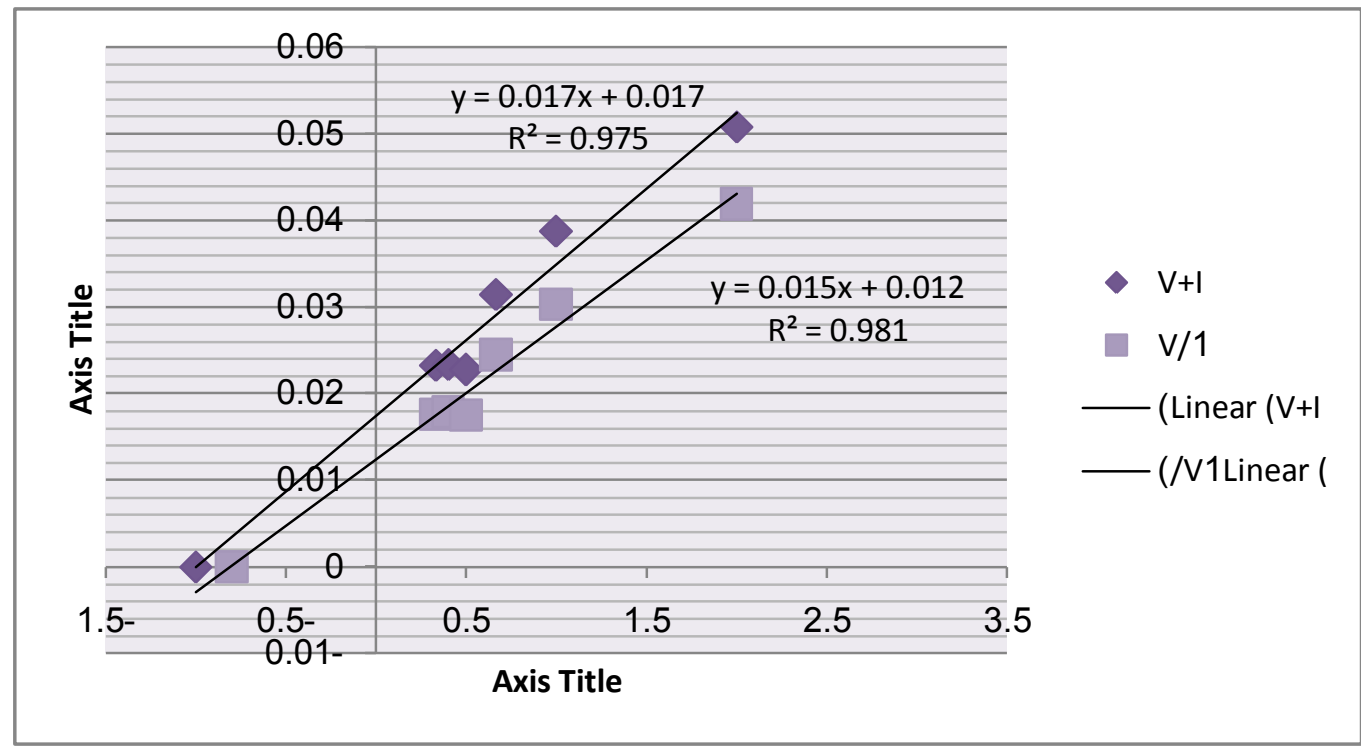

Fig(3): Lineweaver Burk plot for serum GGT with $\gamma$-glutamyl p-nitroanilide as substrate and L-threonine as inhibitor

\section{Discussion:}

Our results showed that L-threonine could affect activity of GGT enzyme. Data from our study indicate that L-threonine amino acid inhibited the activity of GGT enzyme.

Elevation of GGT activity can be explained to be due to the affection of liver by damage of liver cells. the relationship between hepatic and serum GGT in human patients has been studied by several authors. Experimental work has mostly used rats. Who have substantially lower serum and hepatic GGT activity than humans(Teschke et al,1983).found 20 fold higher values in normal humans than in control rats. As so much work is based on these animals,the assumption that the difference is purely quantitative is rather a crucial one.

A sensitive method for measurement of GGT activity in needle biopsy samples was developed by (Satoh and Colleogues;1980),found that in 57 patients with a variety of liver diseases either serum or hepatic GGT . or both,or neither,could be elevated . Among those patients with both serum and liver GGT increased, higher values were found in alcoholic or drug-induced hepatitis than in viral hepatitis, and in the former group serum GGT showed a greater increase above normal (approximately six fold) than liver GGT (around three fold).

In the study with S.GGT,it was reported that for gamma-glutamyl p-nitroanilide and glycyglycin, the $\mathrm{Km}$ values were $1.9 \mathrm{mM}$ and $12.0 \mathrm{mM}$ respectively (Rosalki and Tarlow ,1974). The $\mathrm{Km}$ value of human liver GGT, when gamma-glutamyl p-nitroanilide was used as the substrate, was reported as $1.4 \mathrm{mM}$, and for kidney it was $1.2 \mathrm{mM}$ ( Shaw et al,1978).

It was reported in the literature that L-serine (which is another essential amino acid)inhibits GGT in the presence of borate by interacting with the gamma-glutamyl binding site of the enzyme(Tate and Meister,1978; Vesely et al ,1985).GGT activity is increased in a number of primary and metastatic 
tumers(Dominici et al,2003). It has been shown that hepatocellular carcinoma can be expressed hepatoma specific GGT and secreted GGT in to circulating blood(Yao et al,1998).

In the conclusion,our experiment demonstrared that L-threonine amino acid, or food that contain this type of amino acid might provide to be a valuable tool for the treatment of liver diseases.

\section{Reference:}

[1]. Benakappa.S.,Varghese, T.J. Dietary threonine requirement of Indian Major Carp,Cirrhinus Mrigala (Hamolton),Juveniles. The Israeli J. of Aquaqulture-Bamidgeh.2013,339(6116);222-226.

[2]. Curthoys,N.P. and Hughey,R.P. Characterization and physiological function of rat renal gamma-glutamyltranspeptidase. Enzyme.1979,24;383-403.

[3]. Dominici, S.,Pieri, L.,Comporti, M. and pompella,A. Possible role of membrane gamma-glutamyltransferase activity in the facilitation of transiferrin-dependent and independent iron uptake by cancer cells. Cancer Cell Int. 2003,3;7-15.

[4]. Elce,J.S. and Broxeyer,B. Gamma-glutamyl transferase of rat kidney. Simultaneous assayof the hydrolysis and transfer reaction with (glutamate-14C)glutathione. Biochem.J.1976,153;223-232.

[5]. Hanigan,M.H.,Gallagher,B.C.,Townsend,D.M. and Gabarra,V. Gamma-glutamyltranspeptidase accelerates tumor growth and increase the resistance of tumor to cisplatin in vivo. Carcinogenesis. 1999,20;553-559.

[6]. Huseby,N.E.,Multiple forms of serum gamma-glutamyltransferase:association of the enzyme with lipoproteins. Clin chem. Acta 1982,124;103-112.

[7]. Lee,D.S.,Evan,J.C.,Robins,S.J.,Wilson,P.W.,Albino,I.,Fox,C.S,Wang,T.J.,Benjamin,E. J.,D' Agotino,R.B. and Vasan,R.S. Gammaglutamyltransferase and metabolic syndrome,Cardiovascular disease and motality risk:the Framingham heart study. Arterioscler.Thromb.Vasc.Biol.2007,27;127-133.

[8]. Lowry,M.H.,McAllister,B.P.,Jean,J.C.,Brown,L.A.,Hughey,R.p.,Cruikshank,W.W.,Amar,S.,Lucey,E.C.,Braun,K.,J,Johnson,P.,Wight ,T.N. and Joyce-Brady,M. Lung lining fluid glutathione attenuates IL-13-induced asthma. Am.J.Respir.Cell.Mol.Biol. 2008,38;509516.

[9]. Moss, G.P.,Nomenccature and symbolism for amino acids and peptides(IUPAC- IUB recommendations ). Pure Appl. Chem. 1984,56(5):595-624.

[10]. Nemesanzky, E. and Lott,J.A. Gamma-glutamyltransferase and its isoenzymes:progress and problems. Clin. Chem. 1985,31;797-803.

[11]. Rosalki, S.B. and Tarlow,D. Optimaized determination of gamma-glutamyltransferase by reaction rate analysis. Clin.Chem. 1974,20;1121-1124.

[12]. Satoh T.,Takenaga M., and Kitagawa H. Microassay of gamma-glutamyltranspeptidase in needle biopsies of human liver. Res Commun Chem pathol pharmarmacol . 1980,30;151-61.

[13]. Sener, A. Gamma-glutamyltransferase. Biyok omya Dergisi 1997,22;27-33.

[14]. Shaw, L.M., London, J.W. and Petersen,L.E. Isolation of gamma-glutamyltransferase from human liver and comparison with the enzyme from human kidney. Clin. Chem. 1978,24;905-915.

[15]. Szasz G. Methods of enzymatic analysis. $19742^{\text {nd }}$ ed. 2.p.715.

[16]. Szasz,G. A kinetic photometric method for serum gamma-glutamyltranspeptidase. Clin.Chem. 1969,15;124-135.

[17]. Tate, S.S. and Meister, A. Serine borate complex as a transition state inhibitor of gamma-glutamyltranspeptidase. Proc. Natl. Acad. Sci. 1978,$75 ; 4806-4809$.

[18]. Teschke R.,Neuefeind M., and Nishimurm M. Hepatic gamma-glutamyltransferase activity in alcoholic fatty liver: comparison with other liver enzymes in man and rats. Gut 1983,24;625-30.

[19]. Vesely,J.,Lisy,V. and Cernoch,M. Partial purification of gamma-glutamyltransferase from brain microvessels . Neurochem. Res. 1985,$10 ; 1325-1334$.

[20]. Wenham,P.R., Horn,D.B.,Smith,A.F., physical properties of gamma-glutamyltransferase in human serum. Clin. Chem.Acta. 1984,$141 ; 205-218$.

[21]. Whitifield J.B.,Gamma-glutamyltransferase,Crit.Rev.Clin.Lab Sci. 2001,38;261-355

[22]. Wickham,S.,West,M.B.,Cook,P.F. and Hanigan,M.H. Gamma-glutamyl compounds:Substrate specificity of gammaglutamyltranspeptidase enzyme. Anal.Biochem.2011,414;208-214.

[23]. Xu W.,Shiyan, Q., Yulong Y., Longyao Y., Zongyi W.and Guoyao W. Adeficiency or excess of dietary threonine reduces protein synthesis in jejunum and skeletal muscle of young pigs. J.Nutr. 2007,137(6):1442-1446.

[24]. Yao, D.F.,Huang.Z.W., Chen,S.Z.,Huang, J.F., Lu, J.X., Xiao, M.B. and Meng,X.Y. Diagnosis of hepatocellular carcinoma by quantitative detection of hepatoma specific bonds of serum gamma-glutamyltransferase. Am.J.Clin.Pathol. 1998,110;743-749. 